\title{
Growth and water content of the eyeball of the albino rat in protein deficiency
}

\author{
By D. S. McLAREN* \\ Human Nutrition Research Unit, Nutrition Building, National Institute \\ for Medical Research, The Ridgeway, London, N.W. 7
}

(Received 12 December I957)

Protein malnutrition has been described (Brock \& Autret, 1952) as 'the most serious and widespread nutritional disorder known to medical and nutritional science'. Many aspects of protein deficiency in the rat have been studied, but little attention has been paid to its effects on the eye. The observations presented here were made as part of a study of the changes resulting from the feeding of rats on diets low in protein, designed to simulate those commonly consumed by some malnourished human communities.

\section{Growth of the eye}

In his extensive studies on the effects of partial and total inanition on the growth of various organs of the albino rat, Jackson (1925) found that the eye was one of the organs least affected, and that in this respect it resembled the brain and spinal cord. The method used was to hold constant the body-weight of young rats of various ages, for varying periods of time, by underfeeding. He compared the final weights of the organs with those of body-weight controls. Barry (1920) made a similar study of the organ weights of newborn rats from dams underfed during the latter half of pregnancy. In a comparison with control foetuses of the same body-weight he found that, next to the spleen, the eye showed the greatest increase in weight.

Using a diet low in protein, Limson \& Jackson (1932) found that after about 4 months, the eyes of rats fed on it were more than half as heavy again as those of bodyweight controls which had been killed at weaning. The experimental animals slowly lost weight, and in order to bring their body-weight back to that of the controls, they were given a casein supplement towards the end of the experimental period. In this study, next to the spinal cord, the eyes showed the greatest increase in weight of any organ. It was found by Addis, Poo \& Lew (1936) that in albino rats during a fast the only organs from which there was no loss of protein were the eyes, the testicles, and the adrenals.

The effect of certain amino-acid deficiencies on the growth of various organs of the albino rat was studied by Lafon (1939). The eye, kidney and testicle appeared to go on growing 'at the expense' of other organs. Similar results in the offspring were obtained when a maternal dietary deficiency of lysine and cystine was produced. There seemed to be no significant difference between the effects of the two diets, which is surprising, as cystine in the presence of adequate methionine is now known not to be essential.

* Present address: East African Institute for Medical Research, Mwanza, Tanganyika. 


\section{Water content of the eye}

Lowrey (1913) showed that the dry substance of the eye of the rat increases with age. More detailed investigation of the changes by Donaldson \& King (1936) demonstrated that there is an increase in the percentage of water up to about the $15^{\text {th }}-25^{\text {th }}$ day of life, and thereafter a slow and continuous fall with increasing age. They thought this change in water content might be related to the opening of the eyes occurring about this time.

Lafon (1939) in his experiments with rats on diets deficient in either lysine or cystine, found that in both groups the percentage dry weight of the eyes was greater in the animals on the deficient diets than in the corresponding body-weight controls.

\section{METHODS}

Rats. The rats from the stock colony were Wistar albino, reared in the Human Nutrition Research Unit and known as Glaxo as they were originally obtained from Glaxo Laboratories Ltd, 7 years ago. Results are also given for members of a colony of low-protein rats which has recently been developed in this laboratory (Platt \& Miller, 1957). In all, I63 control and $\mathrm{I} 47$ protein-deficient rats were used.

Diets. The control diet was diet 4r B (Bruce \& Parkes, 1956). Three diets low in protein were used. They were diets $\mathrm{I}$ and 3 , given to normal-colony rats from weaning, and diet 2, given from weaning to rats of the low-protein colony. All rats were weaned at $2 \mathrm{I}$ days of age.

Diet I had the following percentage composition: casein 3, salt mixture 3, yeast 2, maize starch 92. It provided about $4 \%$ protein and in addition was very low in fat. The vitamins of the $\mathrm{B}$ complex were in lower concentration than recommended for normal rats. It was found that animals on this diet consumed nearly $10 \mathrm{~g} /$ day, but grew to about half the size of normal rats. Signs of deficiency of B vitamins were absent, and supplementation with $B$ vitamins failed to increase the rate of growth. Fatsoluble vitamins were given by mouth each week. Thus in respect of protein, fat, calories and B vitamins this diet closely resembled the dietaries of children in some malnourished human groups.

Diet 2, for rats of the low-protein colony, had the following percentage composition: whole-wheat flour 80, potato starch 10, haricot bean 5 , lucerne meal 2, arachis oil 2, salt mixture $\mathrm{I}$. The protein $(\mathrm{N} \times 6.25)$ content was $10.8 \%$. Mixtures of fat-soluble and water-soluble vitamins were added. In order to obtain satisfactory litters and to rear them consistently it was found necessary to supplement this diet during gestation and lactation with $10 \%$ white-fish meal, bringing the protein content up to $17 \cdot 6 \%$.

Diet 3 consisted of brown cassava to which vitamins and minerals were added. This diet has been used in this laboratory (Balfour, 1955) in studies on the effects of diets very low in protein on the liver, pancreas, and salivary glands. In many parts of Africa and Asia cassava is the staple food. It contains only about I or $2 \%$ protein and is poor in all the essential amino-acids, especially in the sulphur-containing amino-acids, methionine and cystine (Bigwood, 1953).

Preparation of eyes. The animals were killed by coal-gas asphyxiation if more than 
5 weeks old. Younger rats were killed by cutting off the head. The eyeball was rapidly removed, and muscle, fat and palpebral conjunctiva were trimmed. The dry weight of the organ was estimated after it had been dried overnight at $105^{\circ}$. All the weighings were correct to $0 . \mathrm{I} \mathrm{mg}$.

\section{RESULTS}

Figs. I and 2, which have been constructed from the values for the fresh weight of both eyeballs of control and deficient rats, respectively, show the growth of the eyeball before and after weaning. Results for the sexes are pooled as it was found, in accordance with the report of Krause ( $(934)$, that the absolute weight of the eyeball is

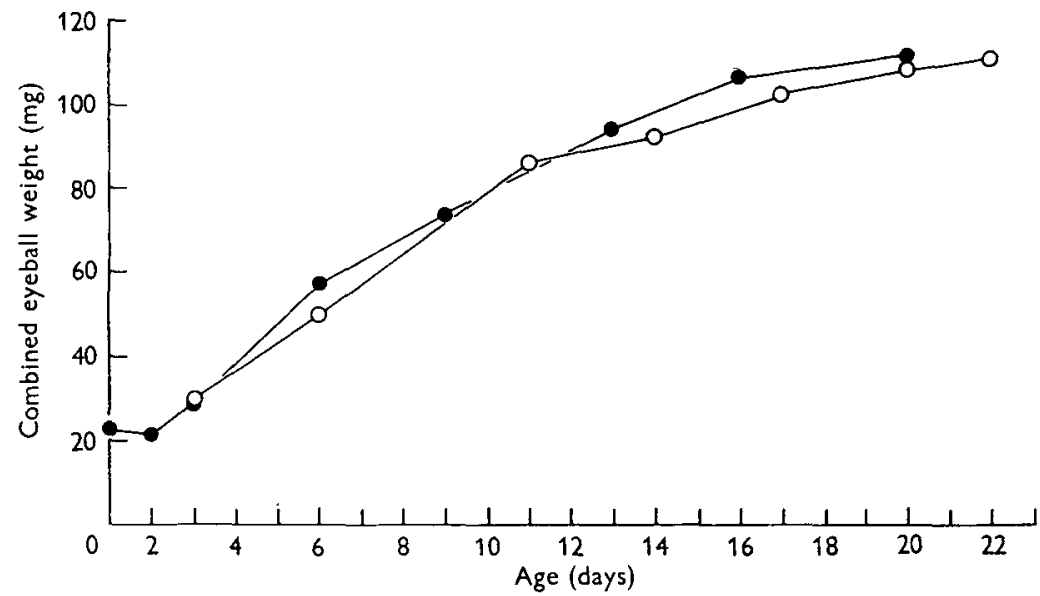

Fig. 1 . Growth of the eyeball before weaning in rats from a colony fed on a normal diet, $\bullet-\bullet$, and from a colony fed on a low-protein diet (diet 2, see p. 255), $0-0$.

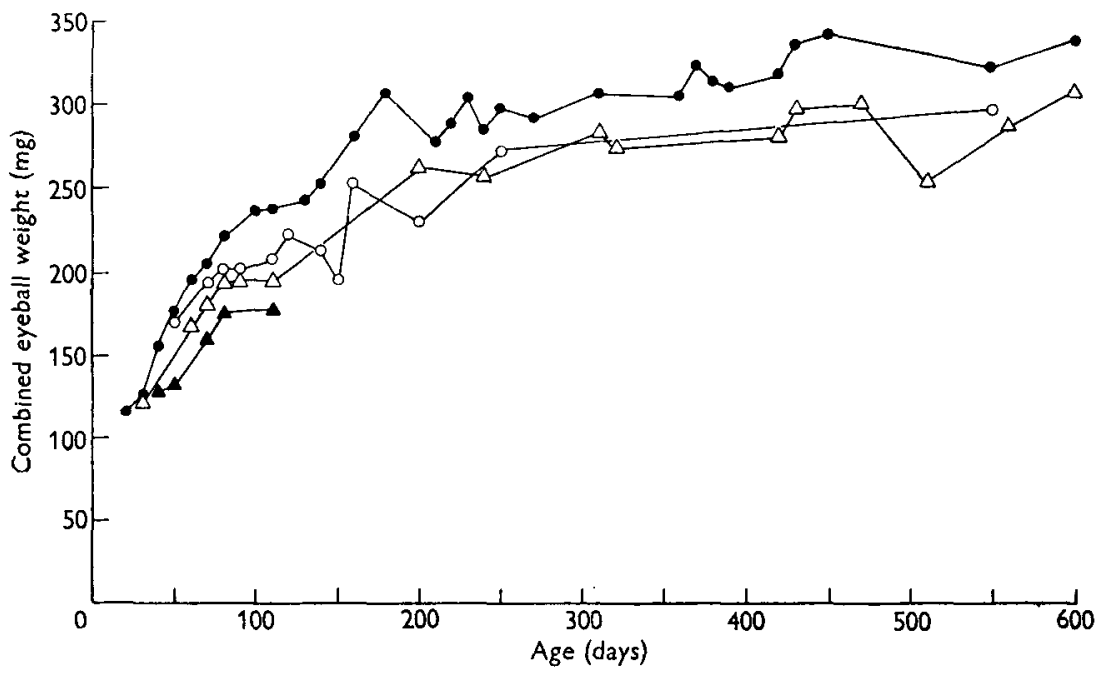

Fig. 2. Growth of the eyeball after weaning in rats fed on a normal diet, and on low-protein diets. $\bullet-\bullet$, normal diet; $\Delta-\Delta$, diet $\mathbf{1} ; 0-0$, diet $2 ; \Delta-\Delta$, diet 3 (see p. 255). 
approximately the same in the two sexes. The results before weaning are grouped according to age in days, but thereafter are grouped together in ro-day age groups.

Fig. 3 shows the change with age in the percentage dry weight of the eye in control and deficient rats, the value for each animal being the mean of the values for the two eyes. No sex difference was evident, and the results have been pooled.

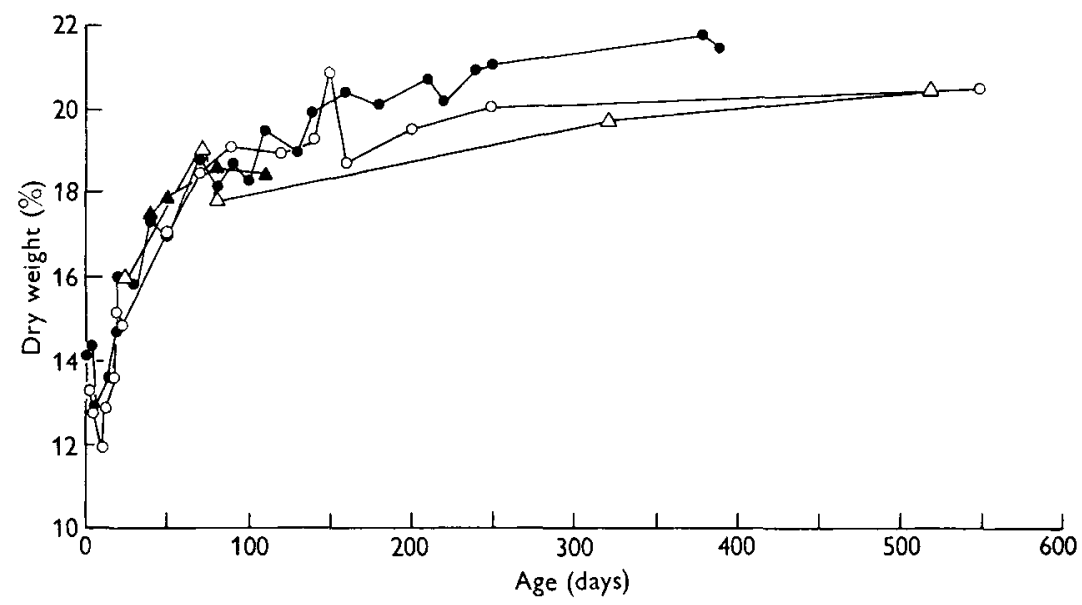

Fig. 3. Dry weight of the eyeball of rats fed on a normal diet and on low-protein diets. $\bullet-\bullet$, normal diet; $\Delta-\Delta$, diet $\mathbf{I} ; 0-0, \operatorname{diet} 2 ; \mathbf{\Delta} \mathbf{\Delta}$, diet 3 (see p. 255).

\section{DISCUSSION}

Growth. From Fig. I it can be seen that there is a rapid increase in the weight of the eye from just over $20 \mathrm{mg}$ for the combined eyeball weight at birth to more than five times this figure by weaning. The growth curves for the control rats and for those of the low-protein colony are almost identical.

Fig. 2 shows that until about 6 months of age the eye of the rat continues to grow steadily. After this time there is a further slight increase in weight, going on at least until nearly the end of the 2nd year of life. In the rat the lens accounts for something like $30 \%$ of the total fresh weight of the eye. It is possible that the continuous proliferation of lens fibres, going on throughout life, may be partly responsible for this continuing increase in weight. Recently, Dische, Borenfreund \& Zilmenis (I956) have shown that there is a rapid increase in the weight of the lens during the ist year, and that after about $\mathrm{I} \frac{1}{2}$ years of age there is still a slight increase.

After weaning, the eyes of rats of the low-protein colony, fed on diet 2, were consistently lighter than those of the controls, which is in contrast to the findings before weaning, and would seem to indicate that the diet supplemented with $10 \%$ fish meal during lactation gives the animal a good start which it is unable to maintain on the basal diet without supplementation after weaning.

That the level of protein alone cannot account for differences in growth is shown by the almost identical curves for rats on diets I and 2, despite the fact that the protein contents were 4 and $10.8 \%$, respectively. 
Very low levels of protein and marked deficiencies of essential amino-acids both operated in the greater retardation of growth of the eyeballs of rats fed on diet 3 . The resistance of the eye to the deleterious effects of such gross nutritional deficiency is shown by the continued increase in the weight of the eye, despite a slow but steady loss of body-weight from weaning. The values for rats fed on diet 3 were only about $25 \%$ less than those for the age controls.

Water content. From Fig. 3 it may be seen that my results confirm the general percentage increase of dry substance with age previously found, and also the exceptional period before weaning in which the water content was temporarily increased. This increase of water content in the period from about the $5^{\text {th }}$ to the $15^{\text {th }}$ day was seen in both the control rats and those of the low-protein colony.

The close similarity of the values from weaning until about 100 days of age for both the control and the experimental rats on the three low-protein diets, evident from Fig. 3, indicates that even in severe protein deficiency the water content of the eye is not changed. Thus the suggestion of Jackson (IgI5), which he made on the basis of Lowrey's ( $\mathrm{I}^{\mathrm{I}} 3$ ) data, that the high water content of the eye would explain its continued growth in states of inanition by increase in water content, cannot be upheld. Despite a low dietary protein, together with an imbalance of essential amino-acids, the eyes of the rats continued to increase in total weight, and at the same time maintained the same order of percentage increase in dry weight as those of control animals.

\section{SUMMARY}

I. The growth of the eyeball of albino rats, as measured by the increase in fresh weight, was studied in animals fed on three diets low in protein. Even with very low levels of protein and marked imbalance of essential amino-acids, growth continued, and the retardation observed was never more than about $25 \%$ compared with controls of the same age.

2. The changes in water content of the eye with age which were described by Donaldson \& King (1936) have been found to occur also in rats fed on low-protein diets.

This work was carried out whilst I was a Colonial Medical Research Student, and forms part of a thesis submitted in partial fulfilment of the regulations for the degree of Ph.D. in the University of London. I wish to acknowledge the constant interest and help of Professor B. S. Platt, C.M.G., Director, Human Nutrition Research Unit, Medical Research Council.

\section{REFERENCES}

Addis, T., Poo, L. J. \& Lew, W. (I936). F. biol. Chem. xr5, III.

Balfour, B. M. (1955). Unpublished observations.

Barry, L. W. (1920). Publ. Carneg. Instn. (Contr. to Embryol.) r1, 93.

Bigwood, E. J. (I953). Experientia-Supplementum I, Verlag Birkhäuser, Basel.

Brock, J. F. \& Autret, M. (1952). Bull. World Hlth Org. 5, I.

Bruce, H. M. \& Parkes, A. S. (1956). F. Anim. Tech. Ass. 7, 54.

Dische, Z., Borenfreund, E. \& Zilmenis, G. (1956). Arch. Ophthal., N.Y., 55, 471.

Donaldson, H. H. \& King, H. D. (1936). Amer. F. Anat. 60, 203.

Jackson, C. M. (I9I5). F. exp. Zool. 19, 99. 
Jackson, C. M. (1925). The Effects of Inanition and Malnutrition upon Growth and Structure. London: J. and A. Churchill.

Krause, A. C. (I934). The Biochemistry of the Eye. Baltimore: Johns Hopkins Press.

Lafon, M. (1939). Ann. Physiol. Physicochim. biol. 15, I.

Limson, M. \& Jackson, C. M. (1932). F. Nutr. 5, I63.

Lowrey, L. G. (1913). Anat. Rec. 7, 143.

Platt, B. S. \& Miller, P. J. (1957). Proc. Nutr. Soc. 16, ix.

\title{
The influence of alternate high-protein and low-protein feeding on growth and reproduction and on regeneration of haemoglobin in rats
}

\author{
BY ANNA W. I. vAN DAM-BAKKER, A. P. DE GROOT AND R. LUYKEN \\ Central Institute for Nutrition Research T.N.O., Utrecht, The Netherlands \\ (Received 8 Fanuary 1958-Rerised I7 March I958)
}

In some tropical areas nutrition is characterized by an irregular protein intake, meals containing little or no protein alternating with meals very rich in proteins. Such a food habit was observed by Luyken \& Luyken-Koning (1955) in the south of Netherlands New Guinea, where the protein intake is temporarily very high after a day of hunting or fishing, but afterwards almost only carbohydrates (in the form of sago) are consumed for days on end.

Animal experiments have shown that a diet is not optimal when the protein fraction is given separate in time from the rest of the diet. Cuthbertson, McCutcheon \& Munro (1940) observed that in adult rats, which in the morning were fed on a proteinfree meal followed by a given amount of protein in the afternoon, the nitrogen retention was lower than when both fractions were administered as a mixture, and Geiger (1948b) showed that the growth of rats, which overnight had a protein-free ration, but during $2 \mathrm{~h}$ of the day could eat so much of a protein mixture that the total diet contained $20 \%$ protein, was less than that of control rats which received the same quantities of food as a mixture.

Animal experiments have likewise demonstrated that two deficient proteins, which in combination form a good protein mixture (e.g. yeast protein and wheat gluten), do not supplement each other when they are given with an interval (Geiger, I948 $a$; Henry $\&$ Kon, $1945^{-6)}$. This effect appeared also from alternate administration of a deficient protein and the lacking amino-acid (Geiger, 1947). All these experiments were continued for only a short time. It seemed of importance to us to study the influence of alternate feeding of a high-protein and a low-protein ration to rats over a longer period of observation. In these experiments we determined growth rate, fertility, haemoglobin content and recovery of the haemoglobin level after experimentally induced anaemia.

The anaemia served as a stress factor to make the experiment more readily comparable with the human conditions to which we wish to relate the experimental results. 